\title{
Correction to: Adherence to prescription guidelines and achievement of treatment goals among persons with coronary heart disease in Troms $\varnothing 7$
}

\author{
Elisabeth Pedersen ${ }^{1^{*}} \mathbb{0}$, Beate Hennie Garcia' ${ }^{1}$ Kjell H. Halvorsen ${ }^{1}$, Anne Elise Eggen ${ }^{2}$, Henrik Schirmer ${ }^{3,4}$ and \\ Marit Waaseth ${ }^{1}$
}

\section{Correction to: BMC Cardiovasc Disord (2021) 21:44}

https://doi.org/10.1186/s12872-021-01866-1

Following publication of the original article [1], the authors would like to correct some information in the fourth paragraph under 'Data extraction' in the methods section. We have found that the LDL-cholesterol concentrations included in the study were measured directly, not calculated from total cholesterol.

The information originally read:

Serum total cholesterol was analysed by CHODPAP enzymatic colorimetric methods with commercial kits (Roche Diagnostics GmbH, Mannheim, Germany) from non-fasting blood samples. The analysis was performed at the Department of Laboratory Medicine, University Hospital of North Norway, Tromsø, Norway. LDL-cholesterol concentration was then calculated according to Friedewald's formula: LDL-cholesterol = total cholesterol - high-density lipoprotein cholesterol $-(0.45 \times$ triglycerides $)$.

The information should read:

LDL-cholesterol was collected and analyzed by trained personnel using enzymatic colorimetric methods with

The original article can be found online at https://doi.org/10.1186/s12872021-01866-1.

*Correspondence: elisabeth pedersen@uitno

${ }^{1}$ Department of Pharmacy, UiT The Arctic University of Norway, Troms $\varnothing$,

Norway

Full list of author information is available at the end of the article commercial kits on a Cobas 8000 c702 (Roche Diagnostics $\mathrm{GmbH}$, Mannheim, Germany) from non-fasting venous blood samples. The analysis was performed at the Department of Laboratory Medicine, University Hospital of North Norway, Tromsø, Norway (ISO certification NS-EN ISO 15189:2012).

The original article [1] has been corrected.

\section{Author details \\ ${ }^{1}$ Department of Pharmacy, UiT The Arctic University of Norway, Troms $\varnothing$, Norway. ${ }^{2}$ Department of Community Medicine, UiT The Arctic University of Norway, Troms $\varnothing$, Norway. ${ }^{3}$ Department of Cardiology, Akershus University Hospital, Lørenskog, Norway. ${ }^{4}$ Institute of Clinical Medicine Campus Ahus, University of Oslo, Oslo, Norway.}

Published online: 24 August 2021

\section{Reference}

1. Pedersen $\mathrm{E}$, Garcia BH, Halvorsen $\mathrm{KH}$, et al. Adherence to prescription guidelines and achievement of treatment goals among persons with coronary heart disease in Tromsø 7. BMC Cardiovasc Disord. 2021;21(1):44.

\section{Publisher's Note}

Springer Nature remains neutral with regard to jurisdictional claims in published maps and institutional affiliations.

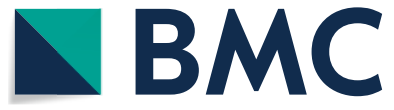

(c) The Author(s) 2021. Open Access This article is licensed under a Creative Commons Attribution 4.0 International License, which permits use, sharing, adaptation, distribution and reproduction in any medium or format, as long as you give appropriate credit to the original author(s) and the source, provide a link to the Creative Commons licence, and indicate if changes were made. The images or other third party material in this article are included in the article's Creative Commons licence, unless indicated otherwise in a credit line to the material. If material is not included in the article's Creative Commons licence and your intended use is not permitted by statutory regulation or exceeds the permitted use, you will need to obtain permission directly from the copyright holder. To view a copy of this licence, visit http://creativecommons.org/licenses/by/4.0/. The Creative Commons Public Domain Dedication waiver (http://creativecommons.org/publicdomain/zero/1.0/) applies to the data made available in this article, unless otherwise stated in a credit line to the data. 